\title{
THE INFLUENCE OF DIALECT ON THE STUDENT'S PRONUNCIATION IN SPEAKING ABILITY
}

\author{
Syahreni Siregar \\ Institut Agama Islam Negeri (IAIN), Metro \\ Email: renisrg@gmail.com
}

\begin{abstract}
Dialect is one of the important aspects in language and communication. So that it will also influence the language teaching process. This article aims to discuss deeply about how dialect can influence on the student's pronuncition in speaking ability. The diversity of Indonesian people influence students' ability in understanding the subject which learned. One of the diversity is language variation in their daily life which called dialect. Every dialect will have uniqueness when speaking. It influences their ability when speak English. Pronunciation is one of the most important parts of English to communicate with the other people since there are differences between symbols and sounds. To communicate with other people in foreign labguage we should have a good pronunciation so that the listener can understand what we mean and there is no missunderstanding between the speaker and the listener. So, this article will try to discuss about the influence of dialect on the student's pronunciation in speaking ability.
\end{abstract}

Keywords: Dialect, Pronunciation, and speaking ability

\section{INTRODUCTION}

Sociolinguistics is a study of language in relation to society. It's a very large field to study and it can be used to describe many different viewpoint of studying language. The important point in sociolinguistics is language. Language is very important means of communication in daily life. Human being use language both written or spoken to express thier idea. Language has sound, form, vocabulary, and grammar. English is a foreign language in Indonesia. To speak English well we should have a good vocabulary and also pronunciation. If we do not have a good pronunciation the listener will be difficult to understand what we mean.
Sometimes, the students are difficult to pronounce the word in English. The students have different ethnics such as lampungnese, sundanese, javanese, bataknese, etc. They used different local language to communicate each other in their own group or community. There are some problems in pronouncing English words which were generally shared by all of the students from all dialect and the problems particularly different from the other and only shared by the students in same dialect.

Pronunciation is one of the most important parts of speaking English to communicate with others since there are differences between the symbol and its sounds. When we 
communicate with other people, we should not only have a good vocabulary but also have a good pronunciation. Therefore, it is important to study about pronunciation.

Speaking ability is the ability to use language with verbal communication by using voice. This skill is needed to communicate one person to each other. Someone who has good ability in speaking usually has many relations and friends, that make the person easier in socialize and do the activities. There are some factors which influence the speaking ability they are comprehension, pronunciation, vocabulary mastery, grammar mastery and fluency. Those factors are usually had by Indonesian students.

Dialect is one of the important aspects in language and communication. So that it will also influence the language teaching process especially on the student's pronunciation in speaking ability. This article will discuss deeply about how dialect can influence on the student's pronunciation in speking ability.

\section{LITERATURE REVIEW Definition of Dialect}

According to Oxford Advanced Learner's Dictionary, dialect is the form of a language that is spoken in one area with grammar, words and pronunciation that may be different from other forms of the same language. Dialect a term widely applied to what are considered sub varieties of a single language. Dialect is a variety of a language used recognizably in a specific region (social dialect) by a specific social class.

According to Jackson and Peter (2011:156) stated that dialect refers to the structural content of speakers' language: the particular words used, characteristic syntactic construction, certain ways of expressing negatives, plurals, tense, and so on. Dialect is a variety of a language used recognizably in a specific region (social dialect) by a specific social class. Dialect has close relation with accent, based on the definition above, finally dialects and accent could be clear distinguished. According to Mayerhoff Miriam (2006:27) Dialect is the variety of vocabulary, syntax, pronunciation. Accent is variety only in pronunciation. Dialect refers to distinctive features at the level of pronunciation and vocabulary and sentence structure .

Anathor linguists, Edward (2009:63) also pointed out dialect as a variety of a language that differs from others along three dimensions: vocabulary, grammar and pronunciation (accent). Because they are forms of the same language, he states also dialects are mutually unintelligible. Indeed language is major part of dialect. The others dialect that is mutually unintelligible for example Dutch and German speaker cannot understand each other even basically both of them have same language, another example is Mandarin and Cantonese, Thai and Lao, Hindi and Urdu, Serbia and Croatian etc.

Haugen points out that, while speakers of English have never seriously adopted patois as a term to 
be used in the description of language, they have tried to employ both language and dialect in a number of conflicting senses. Dialect is used both for local varieties of English, e.g., Yorkshire dialect, and for various types of informal, lowerclass, or rural speech. 'In general usage it therefore remains quite undefined whether such dialects are part of the "language" or not. In fact, the dialect is often thought of as standing outside the language.

\section{Kinds of Dialect}

Wardhaugh (2006:49) stated that dialect mainly consists of two branches namely regional dialect and social dialect.

\section{Regional Dialect}

Regional dialect is geographically based. It means that a dialect that differs because of geographical area. The differences can be in terms of pronunciation, choice of words, and syntax.

The term dialect, pariculary when it is used in reference to regional variation, should not confused with the term accents, standart English, for example is spoken in a variety of accent. often with clear regional social association: thare are accent associated with North America, singapore, india, liverpool (scouse), tyneside(geordie), baston, new york and so on.

\section{Social Dialect}

A sociolect or social dialect is a variety of language (a register) associated with a social group such as a socioeconomic class, an ethnic group (precisely termed ethnolect), an age group, etc.

\begin{abstract}
Sociolects involve both passive acquisition of particular communicative practices through association with a local community, as well as active learning and choice among speech or writing forms to demonstrate identification with particular groups.

Sociolect, defined by Peter
\end{abstract} Trudgill, a leading sociolinguist and philosopher, is "a variety which is thought of as being related to its speakers' social background rather than geographical background". This idea of sociolect began with the commencement of Dialectology, the study of different dialects in relation to social society, which has been established in countries such as England for many years, but only recently has the field garnered more attention. However, as opposed to dialect, the basic concept of a sociolect is that a person speaks in accordance with their social group whether it is with regard to one's ethnicity, age, gender, etc. As William Labov once said, "the sociolinguistic view...is that we are programmed to learn to speak in ways that fit the general pattern of our communities". Therefore, what we are surrounded with in unison with our environment determines how we speak; hence, our actions and associations.

\section{Relationship Between Language and Dialect}

Wardhaugh (2006:49) distinguish the terms language and dialect as follow: Lower part of variety language is dialect and as the main part is language, therefore we can say that Texas English and Swiss German are dialects of English and German. 
Some languages have more than one dialect for instance English are spoken in various dialects. Language and dialect can be the same when language was spoken by a few people and has only one variety but some expert say it is unsuitable to say dialect and language is the same because the requirement of lower part can not be found. We can say also Dialect A, B, C and so on is the part of language $X$ because it is spoken by many varieties dialect $\mathrm{A}$, B, C. Edward (2009) also define dialect as a variety of a language that differs from others along three dimensions: vocabulary, grammar and pronunciation (accent).

Lower part of variety language is dialect and as the main part is language. Language and dialect can be the same when language was spoken by a few people and has only one variety but some expert say it is unsuitable to say dialect and language is the same because the requirement of lower part cannot be found. Edward (2009:63) also define dialect as a variety of a language that differs from others along three dimensions: vocabulary, grammar and pronunciation (accent). Many people there can be no confusion at all about what language they speak. For example, they are Chinese, Japanese, or Korean and they speak. Chinese, Japanese, and Korean respectively. It is as simple as that; language and ethnicity are virtually synonymous (Coulmas, 1999).

Language variety refers to the various forms of language triggered by social factors. Language may change form region to region, from one social to another, from individual to individual, and from situation to situation. This actual changes result in the varieties of language. According to Bell these criteria may be used to distinguish certain languages from others.

There are 7 criterias of language, they are:

a. Standardization

Codification of language: grammars, spelling books, dictionaries, literature. It is possible to teach. To make standardization, it require choosing one elite vernacular and it can be prestigious

b. Vitality The existence of a living community of speakers.

c. Historicity

A particular group of people finds their identity by using a particular Language.

d. Autonom

Other speakers of a language must be felt different from other language.

e. Reduction

Particular variety may be regarded as a sub-variety rather than as an independent entity.

f. Mixture

Feelings about the purity or lack of purity of variety

g. De facto norms

Speakers recognize as 'good' speakers and 'poor' speakers and that the good speakers represent the norms of proper usage. 


\section{Pronunciation}

Pronunciation refers to the production of sounds that people use to make meaning. It is related to the particular sounds of language (segments), aspects of speech beyond the level of the individual sound, such as intonation, phrasing, stress, timing, rhythm (suprasegmental aspects), how the voice is projected (voice quality) and in its broadest definition, attention to gesture and expressions that are closely related to the way people speak language. In English there are 44 phonemes which are consisted by 24 consonants, 12 vowels, and 8 diphtongs.

Then, based on importance of pronunciation, there are some reason why it is important to be investigate. According to Burns, it is more important that speakers of English can achieve intelligibility (the speaker produces sound patterns that are recognisable as English), comprehensibility ( the listener is able to understand the meaning o what is said), and interpretability ( the listener is able to understand the purpose of what is said).

Then, there are some factors may affect the students pronunciation when they put efforts in learning the target language. The factors are various. There are some factors may affect the pronunciation : accent, stress, intonation, and rhythm, motivation and exposure, attitude, instruction, age, personality, and also mother tongue influence. Thus there are some factors that are related to this paper especially in the case of dialect.

For the people who live and share the area with people who comes from the different ethnics that speak different language, it may be obvious that there are some particular accents appeared when the people speak the same language and those accents are primarily the representative for each of ethnic. In fact, for those students who acquired the local language firstly, it is obvious they have certain accents when they speak Bahasa Indonesia and the accents could easily point out from which ethnic she or he come from. As Crystal states that an accent is the cumulative auditory effect of those features of pronunciation that identify where a person is from, regionally or socially.

Each of dialect shares certain languages that has its own way to be uttered that differs from one language to other. Thus, each of language, especially the local language has its own stress, intonation, and speech sounds which are unique and primarily recognized as the identity of the language. In fact, there could be an interference from mother tongue to other language including those features as Crystal states that pronunciation research and teaching focus both on the sounds of language (vowels and consonants) and on supra-segmental features that is, vocal effects that extend over more than one sound such as stress, sentence and word intonation, and speech rhythm.

At the last, since each of languages has its own sound system, the mother language will affect the student pronunciation in learning the other language. Therefore, there is a possibility that the local language that is used in the speech community could affect the pronunciation of English since the local is the first 
language students acquired as Nunan states that when there is a difference in the sound system in the LI and L2 showed, errors are expected to be committed because the learners transfer their mother tongue sound system into the target language. Mother tongue has clear influence on learning L2 pronunciation.

In pronouncing English words, sometimes we find students who hardly try to utter some English words completely and in other case, the students cannot perfectly utter a word that may lead into misscommunication. However, speaking in understandable pronunciation is good to communicate each other

\section{The Concept Of Speaking}

There are many definitions of speaking that have been proposed by some Experts in language learning. According to Brown (2001:140), in his book "Language Assessment Principles and Classroom Practices", speaking is a productive skill that can be directly and empirically observed, those observations are invariably colored by the accuracy and effectiveness of a test-takers listening skill, which necessarily compromises the reliability and validity of an oral production test.

On the other hand, Lucy pollard (2008:33) said that speaking is one of the most difficult aspects for student master. This is hardly surprising when one consider everything that is involved when speaking: ideas, what to say, language, how to use grammar and vocabulary, pronunciation as well as listening to and reacting to the person you are communicating with.

Then, Sari Luoma (2004:9) stated speaking as interaction, and speaking as a social and situationbased activity. All these perspectives see speaking as an integral part of people's daily lives. Together, they help assessment developers form a clear understanding of what it means to be able to speak a language and then transfer this understanding to the design of tasks and rating criteria. In addition, Speaking can be seen from two perspectives: performance and ability. Performance is defined as actual instances of language use in real time which is something that can be observed. On the other hand Rie Ikoizumi (2007:2) stated, ability is an underlying entity that is relatively stable and can be inferred from performance.

From some definitions above, the writer terminates that speaking ability is always related to communication. Speaking ability itself can be stated as the skill to use the language accurately to express meanings in order to transfer or to get knowledge and information from other people in the actual instances of language use in real time.

\section{Speking Ability}

Speaking ability consist of two words. Speaking and ability. AS Harnby (2000:20) states that "ability is the fact that somebody or something is able to do something”. Furthermore, speaking is the activity to use your voice to say something. These can be referred that speaking ability is the fact that somebody is 
able to use his/her voice to say something.

Besides Jack C. Richard (2008: 22) Speaking is a productive skill which needs a lot supporting factors like knowledge, confidence, self esteem and enthusiasm. Speaking a second language, particularly, brings about its own prerequisites. Exposure, consolidation, motivation as well as acknowledgment. It means that speaking is an industrious ability which needs a lot supporting factors.

\section{Function of speaking}

There are three functions of speaking based on Brown and Yule's framework (2001:140). They are:

\section{a. Talk as interaction}

It refers to "conversation". When the people meet, they give and receives greetings, make a chat, retell their experience and so on. It is more focus on the speakers; action and how they show themselves to each other than on the message of conversation.

Conversation takes place in real time, most of daily conversation is spontaneous, unplanned and without preparation. It is happened in real time so we need to think rapidly. This factors causes we often pause our speech and hesitate (using 'er...um') to give ourselves time to think. Most of conversation happen face to face. This allows us to get immediate feedback, use facial gestures, body language, and intonation. When someone talks to the other he/she has purpose in their conversation.

\section{b. Talk as transaction}

Talk as transaction refers to conditions where the focal point is on what is said or done. The message and making oneself understood obviously and precisely is the central focus.

\section{c. Talk as performance}

It refers to public talk, that sends forward information to the audience, such as presentations, public announcements, and speeches. Speaking consist of some basic types, as follow:

1. Imitative, it's like what parrot do, when speaker only imitate the sound without comprehend their speech's meaning.

2. Intensive, it is the higher level than imitative, when the speaker not only imitate but also produce $\mathrm{s}$ and shows their ability in a grammatical, phrasal, lexical, or phonological relationship.

3. Responsive, in this type, there is interaction and comprehension of very short conversation, simple comments and so on.

4. Interactive, it is the higher level of responsive, where it has longer and more complex interaction than in responsive type.

5. Extensive (monologue), it is like speech, sermon, story-telling and so on. 


\section{DISCUSSION}

When we talked abaout educational issues it is concerning that dialect in the English language have received a great deal of college and become an interested attention. Yet overall, college had not satisfactorily addressed these issues. It showed that dialects are a natural, normal aspect of language has been acknowledged only superficially. Educational programs typically do not thoroughly discuss the dialectal distinctions that are clearly applied in the communities they serve or confront the various social attitudes surrounding variation in English. Issues about dialect are not widely understood, and there are many program models to emulate. This article presents some issues relating to students' pronunciation in speaking ability, and describes two kinds of dialects. It also suggests considerations for developing educational policy with respect to dialects and programmatic responds to it.

English speaker can use the vocabulary and grammar of Standard English, but different speakers use their own local words for everyday object or actions, regional accent, and pronunciation. Non-native speakers of English tend to bring over the intonation and phonemic inventory from their mother tongue into their English speech. It causes many students who have different dialect produce different style in their speech.

Speaking is the ability which has been standard in oral communication. Someone who has good ability in speaking will be valued as a master of language. In learning target language, especially in English, many students have difficulties in this ability. That can be caused by many factors, like: motivation, vocabulary mastery, dialect, etc.

The dialect is the most influential factor affecting a learner's pronunciation. Pronunciation is the key of getting full communicative competence. If someone is familiar with the sound system of a learner's dialect, he/she will be better able to know student difficulties. In Indonesia, there are so many tribes which have different language to each other. Every tribe has a unique dialect which be identity of the people who are from that tribe. For example, person who usually uses Bataknese language, he/she will have batak's dialect when he/she speak other language.

Then, there are some factors may influence the students pronunciation when they put efforts in learning the target language. The factors are various, there are some factors may affect the pronunciation : accent, stress, intonation, and rhythm, motivation and exposure, attitude, instruction, age, personality, and also mother tongue influence. Thus there are some factors that are related to this article especially in the case of dialect.

For the people who live and share the area with people who comes from the different ethnics that speak different language, it may be obvious that there are some particular accents appeared when the people speak the same language and those accents are primarily the representative for each of ethnic. In fact, for those students who acquired 
the local language firstly, it is obvious they have certain accents when they speak English and the accents could easily point out from which ethnic she or he come from. As Crystal states that an accent is the cumulative auditory effect of those features of pronunciation that identify where a person is from, regionally or socially.

Each of dialect shares certain languages that has its own way to be uttered that differs from one language to other. Thus, each of language, especially the local language has its own stress, intonation, and speech sounds which are unique and primarily recognized as the identity of the language. In fact, there could be an interference from mother tongue to other language including those features as Crystal states that pronunciation research and teaching focus both on the sounds of language (vowels and consonants) and on supra-segmental features that is, vocal effects that extend over more than one sound such as stress, sentence and word intonation, and speech rhythm.

In pronouncing English words, sometimes we find students who hardly try to utter some English words completely and in other case, the students cannot perfectly utter a word that may lead into misscommunication. However, speaking in understandable pronunciation is good to communicate each other

At the last, since each of languages has its own sound system, the mother language will affect the student pronunciation in learning the other language. Therefore, there is a possibility that the local language that is used in the speech community could affect the pronunciation of English since the local is the first language students acquired as Nunan states that when there is a difference in the sound system in the LI and L2 showed, errors are expected to be committed because the learners transfer their mother tongue sound system into the target language. Mother tongue has clear influence on learning L2 pronunciation.

\section{CONCLUSION}

Dialect is one of the important aspects in language and communication. So that it will also influence the language teaching process. Dialect gives a lot of effect in the language teaching. The dialect is one factor that becomes problem for students in learning a new language. Just as in learning English, certainly a lot of things or speaking difficulties experienced especially since the use of different dialect. Dialect is the most influential factor affecting a learner's pronunciation. Pronunciation is a key to reach full communicative competence. If someone is familiar with the sound system of a learner's native language, he/she will be better able to diagnose student difficulties. In Indonesia, there are many tribes which have different language to each other. Every tribe has a unique dialect which be identity of the people who are from that tribe. For example, person who usually uses Javanese language, he/she will have java's dialect when he/she speak other language. Finally, all the participants of language teaching should aware to concern about 
dialect on students' pronunciation in speaking ability.

\section{REFERENCES}

Brown, H. Douglas, Principles of Language Learning and Teaching $\left(4^{\text {th }} E d\right)$, New York, Addison Wesley Longman, Inc: 2000.

Language Assessment
Principles and Classroom
Practices. New York:
Longman, 2001.

Bell, R. T.Sociolinguistics: Goals, Approaches and Problems. London: Batsford. 1976.

Edward. Language and Identity: An Introduction. Cambridge University Press: New York. 2009.

Ferguson, C. A.Language Structure and Language Use. Stanford, CA: Stanford University Press. 1972.

Howard Jackson and Peter Stockwell, An Introduction to the Nature and Functions of Language, New York, Continuum:2011

Holmes, janet. An Introduction to Sociolinguistic.London : Longman. 1972.

Hudson, R. A.Sociolinguistics. 2nd edn. Cambridge: Cambridge University Press. 1996.

Jack C. Richard, Teaching Listening and Speaking , New York:
Cambridge University Press, 2008.

Lucy Pollard's. Teaching English. Copyright@ Lucy pollard, 2008.

O’Connor, J. D.Better English Pronunciation (New ed.). Cambridge: Cambridge University Press. 2003.

Mayerhoff, Miriam, Introducing Sociolinguistics, New York, Routledge: 2006.

Rie Ikoizumi. Relationships between Productive Vocabulary Knowledge and Speaking Performance of Japanese Learners of English at the Novice Level. University of Tsukuba 2007.

Sari Luoma. Assessing Speaking.Cambridge University Press,2004.

Wardhaugh Ronald. An Introduction to Sociolinguistics. London: lackwell Publishing Ltd. 2006. 